\title{
SURVIVAL OF NATURAL POPULATIONS \\ OF AUSTROPOTAMOBIUS PALLIPES IN RIVERS IN BIZKAIA, BASQUE COUNTRY (NORTH OF IBERIAN PENINSULA).
}

\author{
L. GARCIA-ARBERAS and A. RALLO.
}

Departamento de Zoología, Universidad del País Vasco, Apdo. 644, 48080 Bilbao, Spain.

Reçu le 27 octobre 1997

Accepté le 29 décembre 1998

Received 27 October, 1997

Accepted 29 December, 1998

\begin{abstract}
Some relict populations of the native crayfish Austropotamobius pallipes have been located in rivers in Bizkaia, (Basque Country, Spain), and its population numbers and dynamics, and habitat conditions have been studied for three years. The first descriptive results are given in this paper. The native crayfish populations must be considered residual because of the disrupted area distribution and highly fluctuating demography of the species.

Up to now, the species has been located in more than thirty fluvial areas of relatively high slope and shallow and good quality water: Population characteristics (sex ratio, length and weight relations and length frequency classes) are studied in nineteen cases. Maximal relative population numbers are about 100 captures per hour ; these values are correlated to variables of conductivity, hardness, and concentrations of nitrates, nitrites, magnesium, potassium and ammonium. The degree of mineralization must reach a minimum level and, within the values found in the studied rivers, its increase favours the population of crayfish.

Management measures to conserve native crayfish must include the protection and improvement of their habitat, prevention of access to it:and: to the commencement of a genetic study to palliate the phenomenon of endemism. It would also be highly recommendable to begin experimental restocking of riverbeds now without crayfish fauna and with apparently optimum conditions for the establishment of populations of autochthonous crayfish.
\end{abstract}

Key-words : crayfish, native:species, population, rivers, ecology, Spain.

\section{SURVIVANCE DES POPULATIONS:D'AUSTROPOTAMOBIUS PALLIPES DANS LES RIVIĖRES DU PAYS BASQUE (NORD-DE LA PÉNINSULE IBÉRIQUE).}

\section{RÉSUMÉ}

Un certain nombre de populations d'écrevisses autochtones d'Austropotamobius pallipes a été localisé dans des rivières de Biscaye:(Pays'Basque; Espagne), et l'on s'est livré, durant trois ans, à une étude portant aussi bien sur leurs dynamiques de peuplement que sur leurs conditions d'habitat. Cet article en est une première étude descriptive. Les populations d'écrevisses autochtones doivent être considérées comme. résiduelles en 
raison d'une distribution très éclatée dans la zone dans laquelle on les rencontre, ainsi que de leur démographie qui est des plus fluctuantes.

A ce jour, les espèces ont été localisées dans une trentaine de rivières présentant une pente et une profondeur relativement importantes, ayant une eau d'assez bonne qualité. Les caractéristiques de population (sexe-ratio, rapports de longueur et poids et classes de fréquence de longueur) sont étudiées dans dix-neuf cas. Les nombres relatifs de population tournent au maximum légèrement au dessus de 100 captures par jour ; les valeurs sont en corrélation avec les variables de conductivité, dureté et concentrations de nitrates, nitrites, magnésium, potassium et ammonium. De ce fait, le degré de minéralisation doit atteindre un niveau minimum et, à l'intérieur des valeurs constatées pour les rivières étudiées, son accroissement favorise la population d'écrevisses.

Les mesures administratives destinées à la conservation de l'écrevisse autochtone doivent inclure la protection et la sauvegarde de l'habitat, l'accès en étant restreint et une étude génétique étant initiée, visant à pallier le phénomène de l'endémisme. Il est vivement recommandé par ailleurs de commencer des expériences de repeuplements de rivières dont la faune écrevisse est absente et présentant des conditions apparemment optimales pour l'établissement de populations d'écrevisses autochtones.

Mots-clés : écrevisse, espèces autochtones, population, rivière, écologie, Espagne.

\section{INTRODUCTION AND OBJECTIVES}

Austropotamobius pallipes is a native European species, protected by EC, which played a very important ecological role in fluvial systems, not only in the trophic chain but also in the ecosystem equilibrium (MOMOT, 1995). It is observed as a general fact that when crayfish disappeared, river vegetation increased so much that in some cases dystrophic situations arose. Besides this, an important recreational recourse is lost : crayfish dishes are greatly appreciated in our country.

Some relicted populations of the native crayfish of Austropotamobius pallipes have been located in rivers in Bizkaia, Basque Country, Spain, where it was thought that the species had been rendered extinct by aphanomycosis and by habitat deterioration in a short period on 1978-80.

So, our work aims are :

1. to find out where native populations are now living in Bizkaia ;

2. to characterize the habitat conditions of these fluvial zones ;

3. to evaluate crayfish stocks and conditions ;

4. to work out the relationships between habitat and population conditions.

\section{METHODS}

Rivers where native crayfish lived before their catastrophic disappearance, and probably live at present (a hypothesis based on an earlier survey of river gamekeepers and on habitat conditions) were visited in late spring and early summer (June to early August) in 1994, 95 and 96. Six rivers were specially chosen in order to perform an intensive study. In these sites fluvial conditions were measured : river slope, width and depth, banks and 
vegetation, substrate, temperature, $\mathrm{pH}$, conductivity and chemicals dissolved in water. The biotic index (BMWP) (ALBA-TERCEDOR and SÁNCHEZ-ORTEGA, 1988 ; RICO et al, 1992) was also calculated to evaluate the biological habitat quality. Standard apparatus and methods were used. Throughout the text data are given as average \pm standard deviation (s.d.). For security reasons in order to protect the endangered species, the geographical rivers names are omitted and labels are given as River 1 (R1), River 2 (R2), etc. when required.

Crayfish were caught by hand, at night, at definite times and on specific river section lengths, so that population numbers could be referred to effort rates (captures per hour). Each specimen was measured (length and weight), its sex recorded and then put back into the river. The body length of the crayfish was measured to the nearest $1 \mathrm{~mm}$ in two ways : total length (TL), from the tip of the rostrum to the end of the telson, and cephalotorax length $(\mathrm{CL})$, from the tip of the rostrum to the end of the carapace. Crayfish were also weighted with a dynamometer to the nearest $1 \mathrm{~g}$.

The data matrix (samples, physical and chemical conditions, population numbers and associated values : sex, length and weight measures) was analysed by statistical methods (descriptive statistics, multivariate analysis, etc.) using computer programs (StatGraphics Plus, NTSYS ; ROHLF, 1992). Growth rates are estimated by the comparison of the average total length of the size classes determined by BHATTACHARYA's method (BHATTACHARYA, 1967).

\section{RESULTS AND DISCUSSION}

\section{Presence}

During the three years of the study (1994-1996), 90 chosen rives or different fluvial sections were visited (Figure 1). We found native crayfish in 32 places (36.0\% of total visited), and no crayfish (neither native, nor alien species) in the rest. In some of them the population disappeared while the study was going on. Sites were sampled annually in the six rivers included in the intensive study, so that population numbers and condition temporal changes could be recorded. In other rivers, when populations seemed to be relatively large (above 10 individuals captured per hour), sites were also sampled annually.

\section{Habitat conditions}

All the fluvial zones where native crayfish are now living are small rivers located upstream. The average widths of the wet riverbed are low : for the intensive study width is $1.6 \pm 0.6 \mathrm{~m}$, and the depth never passes $20 \mathrm{~cm}$; the average slope is $8.8 \pm 4.8 \%$. The most frequent substrate is predominantly stony or bare rock, but with patches of sand and even mud. The waters are alkaline, $(\mathrm{pH} 8.2 \pm 0.25)$, with conductivity and hardness of $372 \pm 127 \mu$ Siemens/cm and $13.4 \pm 3.6$ French Degrees, respectively. Temperatures recorded when visiting the sites varied between 16 and $24{ }^{\circ} \mathrm{C}$, with an average of $17.8 \pm 2.1^{\circ} \mathrm{C}$. The principal chemical components showed the following concentrations; the high values of standard deviations proved that water composition (especially potassium and ammonium) are very variable among rivers :

$\begin{array}{lrlrl}\text { Sulphate } & 30.8 \pm 13.7 \mathrm{mg} / \mathrm{l} \\ \text { Chloride } & 14.3 \pm 5.4 \mathrm{mg} / \mathrm{l} \\ \text { Bicarbonate } & 140.22 \pm 30.29 \mathrm{mg} / \mathrm{l} \\ \text { Calcium } & 42.02 \pm 1.23 \mathrm{mg} / \\ \text { Magnesium } & 6.84 \pm 2.53 \mathrm{mg} / \mathrm{l}\end{array}$




$\begin{array}{lrcc}\text { Potassium } & 2.44 & \pm 2.96 \mathrm{mg} / \mathrm{l} \\ \text { Sodium } & 10.34 & \pm 3.53 \mathrm{mg} / \mathrm{l} \\ \text { Nitrate } & 3.12 & \pm 2.52 \mathrm{mg} / \mathrm{l} \\ \text { Nitrite } & 0.02 & \pm 0.01 \mathrm{mg} / \mathrm{l} \\ \text { Ammonium } & 0.17 \pm & \pm .19 \mathrm{mg} / \mathrm{l}\end{array}$

Biotic indices $(131.4 \pm 41.6)$ indicate that the running water is of very good, good or medium quality (in this last case because of organic charge, for the most part).

All these values present normal distribution, except for temperature, potassium and ammonium concentrations, which were normalised when required. All these values are within the ranges cited in other papers published on this matter (ARRIGNON and ROCHÉ, 1983 ; LILLEY et al, 1979 ; SMITH et al., 1996) excepting ammonium, which is much higher in our case.

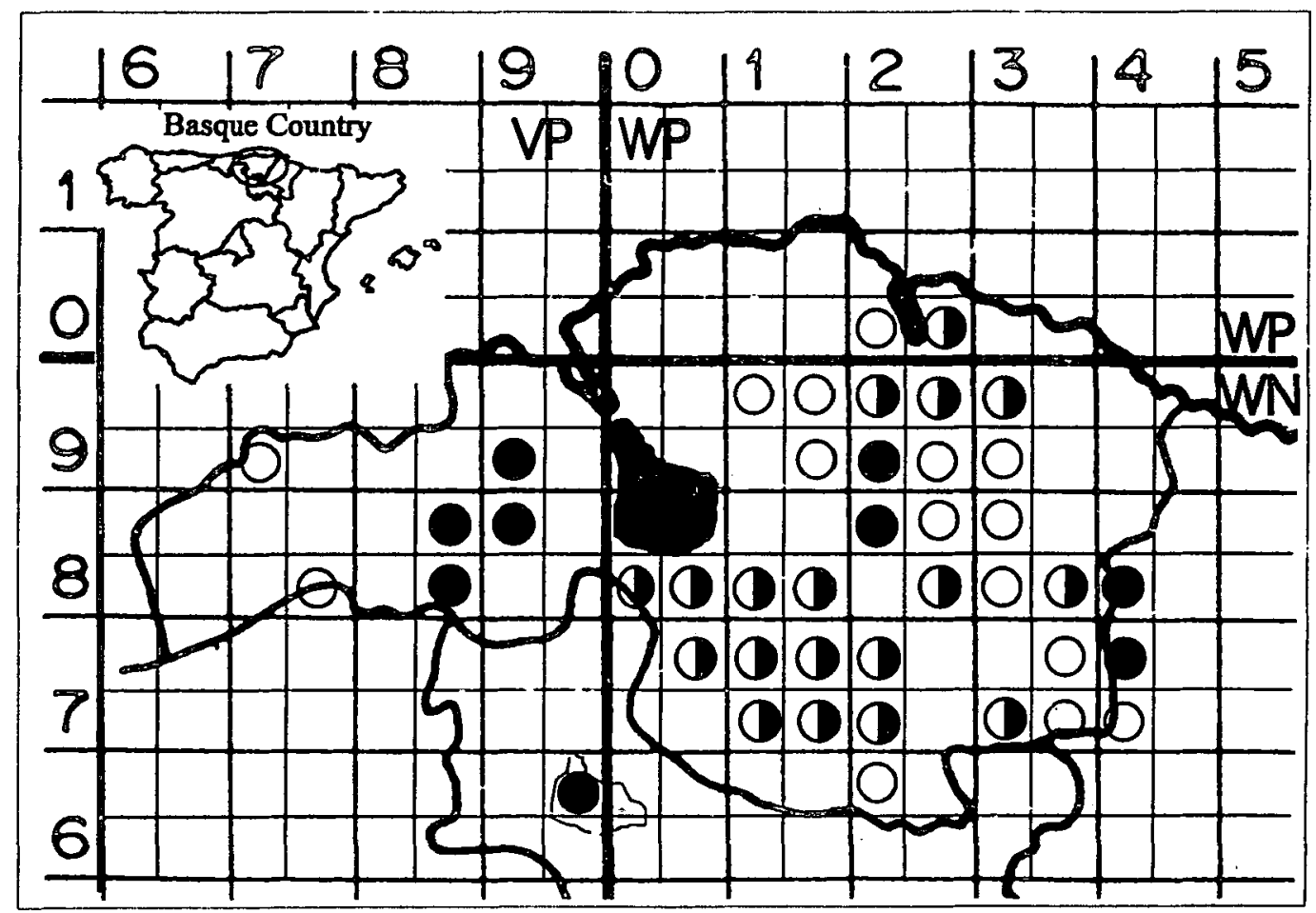

Figure 1

Geographical distribution of Austropotamobius pallipes in Bizkaia : present situation. Sites in UTM. Black circles : presence; empty circles : absence. Half black : either places with and without in the same UTM square or disappearance over time.

Figure 1

Distribution géographique d'Austropotamobius pallipes en Biscaye : situation actuelle. Sites en UTM. Cercles noirs : présence ; cercles vides : absence. Demi-noirs : à la fois endroits avec et sans dans le même carré UTM ou disparition au cours du temps. 
The relationships between samples (from different places or dates and physical and chemical variables of habitat) were determined through multivariate analysis. The similarities between river points are studied by cluster analysis (Figure 2), that allows the identification of groups of similar objects. Three cases (R6_96, R1_96 and R5_96) are separated from all the others, that are grouped first by spatial conditions ( $g r o u p A=\operatorname{river} R 1$ except R1_96; $\mathrm{B}=$ river $\mathrm{R} 2 ; \mathrm{C}=$ river $\mathrm{R} 4 ; \mathrm{D}=$ river $\mathrm{R} 3$, and $\mathrm{E}=$ two rivers, $\mathrm{R} 6$ and $\mathrm{R} 5$, from the same basin, except samples from 1996), and then by time (the most similar are cases from 94 and 95 ).

In order to look deeper into the similarity of cases due to habitat conditions (and not only to time and space factors) data were put through a principal components analysis, so that cases are spatially ordered in relation to principal axes defined by linear combinations of habitat conditions. The first three principal axes extracted (Table I) proved to be significant and explained $78 \%$ of the total variance of the sample. The first one associates bicarbonate and calcium concentrations and total solids on the one hand (negative axis) with ammonium and magnesium on the other (positive), and explains the separation of R1_96 and R5_96 from all the other cases. The second component is related to conductivity, hardness and concentration of chloride, that takes away R6_96, and the third one to organic load measured as QDO. Those cases were also clearly separated by cluster analysis : these are the reasons.

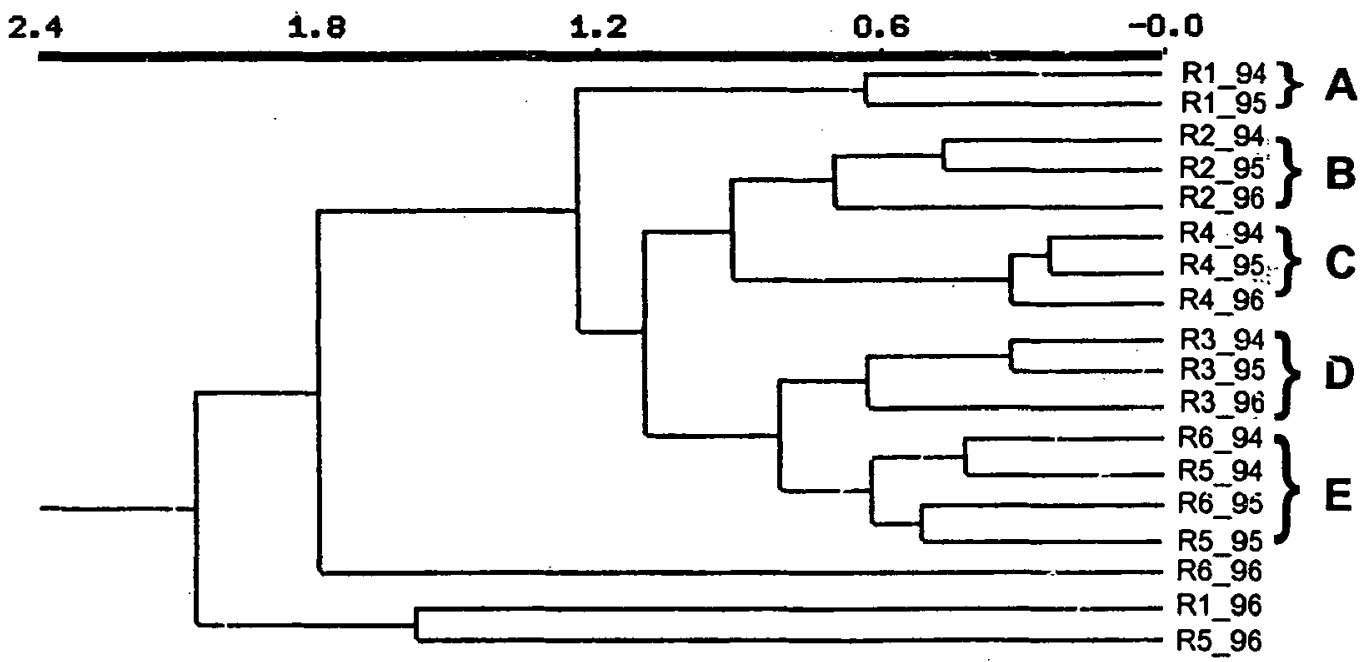

Figure 2

Dendrogram of cases based on habitat conditions. Six sites; three years are represented. (coeff. $=r$ de PEARSON ; agglomerative algorithm : UPGMA; fit of results to original data : correlation of matrices $r=0.8893$, MANTEL $t$-test $=6.962$ ).

Figure 2

Dendrogramme des cas basés sur les conditions d'habitat. Six sites ; trois années sont représentées. (coeff. $=r$ de PEARSON ; algorithme agglomératif : UPGMA ; ajustement des résultats aux données d'origine : corrélation de matrices $r=0.8893$, MANTEL $t$-test $=6.962$ ).

\section{Crayfish stocks and relation to habitat conditions}

The evaluation of relative population numbers measured by catch effort (Figure 3 ) is represented only for the nineteen cases where populations seemed to be relatively high 
(rivers of the intensive study are marked by an asterisk). Population sizes are not large : the maximum reached was over 100 capture/hour, but this quantity must be considered important taking into account the preceding remarks about the size of the rivers or brooks, where native crayfish populations are found. Also this stock is large when compared to other evaluations : the numbers mentioned by ALMAÇA (1989) in Portugal are between 22 and 74 specimen/hour and those found by SMITH et al. (1996) in Southern Britain, 8-31 specimen/hour (as average).

\section{Table I}

Principal component analysis : significance of axes and weight of the variables.

\section{Tableau I}

Analyse des composantes principales : signification des axes et des variables de poids.

\begin{tabular}{|c|c|c|c|c|c|}
\hline $\begin{array}{l}\text { Principal } \\
\text { component }\end{array}$ & Eigenvalue & Percent & $\begin{array}{c}\text { Cumulative } \\
\text { percent }\end{array}$ & Expected & $\begin{array}{c}\text { Axis } \\
\text { significance }\end{array}$ \\
\hline 1 & 6.984119 & 34.9206 & 34.9206 & 17.9887 & yes \\
\hline 2 & 5.564068 & 27.8203 & 62.7409 & 12.9887 & yes \\
\hline 3 & 3.055915 & 15.2796 & 78.0205 & 10.4887 & yes \\
\hline \multirow{23}{*}{$\begin{array}{l}V \\
\mathrm{~T} \\
\mathrm{P} \\
\mathrm{C} \\
\mathrm{Q} \\
\mathrm{C} \\
\mathrm{H} \\
\mathrm{C} \\
\mathrm{S} \\
\mathrm{N} \\
\mathrm{N} \\
\mathrm{P} \\
\mathrm{S} \\
\mathrm{B} \\
\mathrm{C} \\
\mathrm{N} \\
\mathrm{C}\end{array}$} & 1.758120 & 8.7906 & 86.8111 & 8.8220 & not \\
\hline & $\begin{array}{l}\text { Principal } \\
\text { component } \\
\text { axis : }\end{array}$ & 1 & 2 & 3 & \\
\hline & Variables & & & & \\
\hline & Temperature & 0.077 & 0.042 & 0.693 & \\
\hline & $\mathrm{OH}$ & 0.205 & 0.242 & 0.667 & \\
\hline & $\mathrm{O}_{2}$ & 0.545 & -0.115 & 0.663 & \\
\hline & QDO & 0.113 & 0.527 & -0.880 & \\
\hline & Conductivity & -0.022 & 0.955 & 0.210 & \\
\hline & Hardness & 0.057 & 0.952 & 0.109 & \\
\hline & Chloride & -0.221 & 0.909 & 0.149 & \\
\hline & Sulphate & -0.451 & 0.601 & 0.212 & \\
\hline & Vitrate & 0.700 & 0.453 & 0.089 & \\
\hline & Vitrite & 0.735 & 0.161 & 0.040 & \\
\hline & Phosphate & -0.332 & 0.547 & -0.488 & \\
\hline & Silicate. & -0.457 & -0.207 & -0.485 & \\
\hline & Calcium & -0.847 & 0.412 & 0.206 & \\
\hline & Magnesium & 0.864 & 0.417 & -0.153 & \\
\hline & Sodium & -0.540 & 0.670 & -0.112 & \\
\hline & Potassium & 0.557 & 0.793 & -0.157 & \\
\hline & Bicarbonate & -0.925 & 0.168 & 0.235 & \\
\hline & Ammonium & 0.910 & 0.332 & -0.148 & \\
\hline & Total solids & -0.869 & 0.267 & 0.300 & \\
\hline & Biotic Index & 0.717 & 0.048 & 0.203 & \\
\hline
\end{tabular}


The relative population numbers of crayfish have proved to be positively correlated (to a significance level of $95 \% ; r$ of PEARSON ; $n=18$ ) with the following variables : conductivity, hardness and concentrations of nitrates, nitrites, magnesium, potassium and ammonium. All these facts confirm that the degree of mineralization must reach a minimal level and, within the values found in the rivers studied, its increase favours the population of crayfish. The water also has a medium degree of concentration in nutrients (measured by nitrogen compounds), that in our case, on account of the slope, does not cause the oxygen concentration to decline.

Nowadays, we are carrying out studies in order to detect possible differences between the abiotic conditions of groups of cases defined by the presence or absence of native or alien crayfishes.

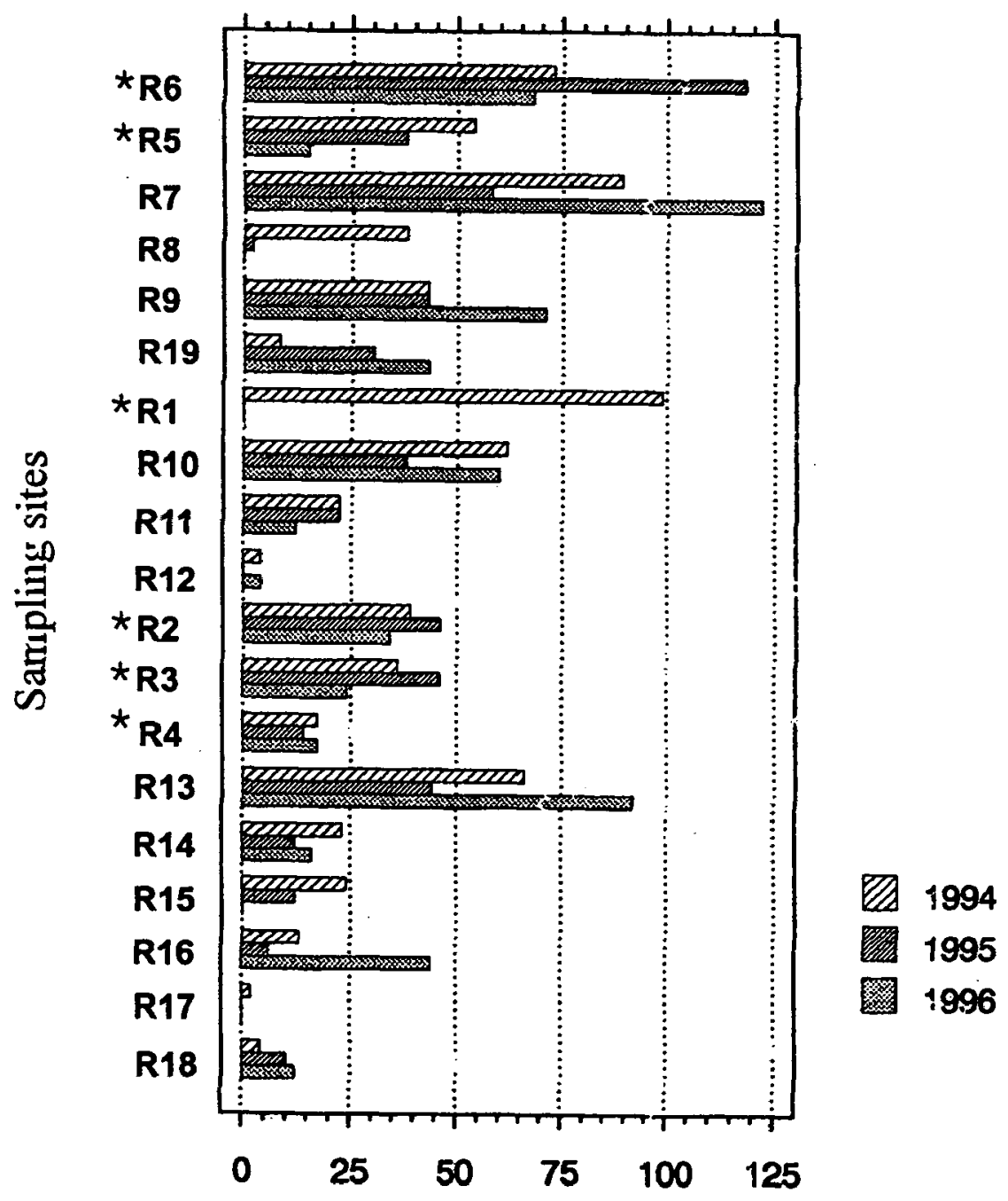

Figure 3

Relative population number estimated by catch's effort rates. Nineteen cases ; three years are represented.

Figure 3

Nombre de population relatif estimé par taux d'effort de captures. Dix-neuf cas ; trois années sont représentées. 


\section{Population structure : sexes, sizes and shapes}

In most cases of studied crayfish populations there were more females than males so that the sexes proportions are not adjusted to the hypothesis $1: 1$ (Figure 4). By applying a $\chi^{2}$ test to check this hypothesis, we found that the likelihood of its being true is $14.98 \%$ for the overall data in 1994 ( $N$, number of crayfish studied, $=696$ ), and lower for 1995 and 1996 $(0.38 \%$, in a sample of $N=276$ and $4.77 \%, N=408$, respectively), so the hypothesis must be rejected. This seems to reflect the actual situation of the population, the manual method of capture and the season given. This preponderance of females has also been detected in other populations (ARRIGNON et al., 1988 ; ARRIGNON et al., 1993 ; SMITH et al., 1996). BERNARDO et al. (1997) found an average sex ratio slightly in favour of females, despite one of the two studied populations was sampled during the reproductive period when part of the females might stay in refuges, thus avoiding capture.

1994

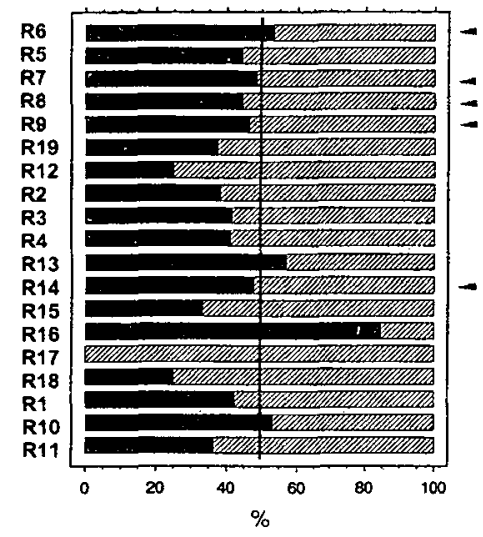

1995

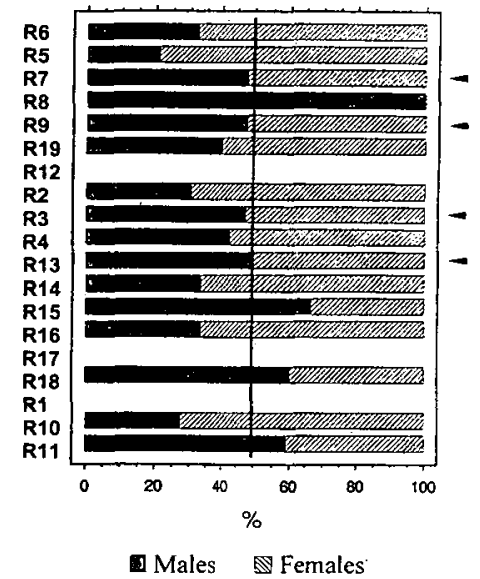

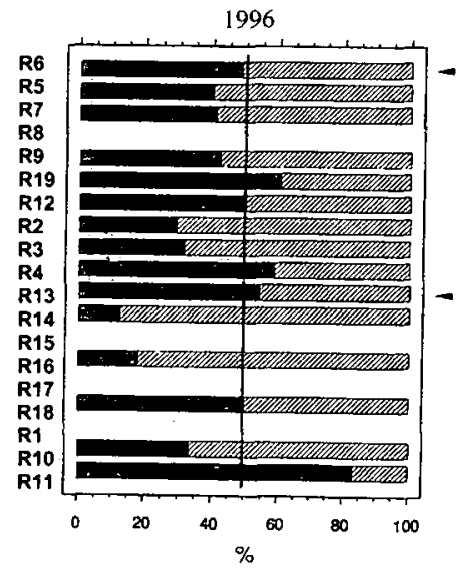

Figure 4

Sex ratios as percentages. Nineteen cases ; three years are represented.

\section{Figure 4}

Sexe ratio en pourcentages. Dix-neuf cas ; trois années sont représentées.

Body sizes of crayfish are studied as total length (TL) from rostrum to telson. Maximum TL found are $111 \mathrm{~mm}$ (male) and $116 \mathrm{~mm}$ (female), that are longer than those cited for other populations (ALMAÇA, 1989 ; ARRIGNON and ROCHÉ, 1983 ; BERNARDO et al., 1997 ; TROSCHEL, 1997). The distribution of length and weight frequencies is different in males and females (analysis made using data from the three years : length $\chi^{2}=54.13, P=0 \%$; weight $\chi^{2}=133.11, P=0 \%$ ). Males are about $1 \mathrm{~g}$ heavier than females (averages: $W_{m}=9.007 \pm 0.351 \mathrm{~g} ; W_{f}=8.004 \pm 0.230$ ), but average length is almost equal in both sexes ( $56.04 \pm 17.98 \mathrm{~mm}$ in males ; $56.34 \pm 17.56 \mathrm{~mm}$ in females). In this, our results differ from those by ALMAÇA (1987) who found females significantly longer than males.

The distribution of length frequencies (as TL, Figure 5) enables us to distinguish four size groups (Table II), which can be interpreted as age groups. The first (length $2.0 \pm 1.1 \mathrm{~cm}$ ), is that of age $0+$, which is difficult to capture. Most crayfish in the river populations belong to size groups II and III (size : $4.1 \pm 0.7$ and $6.3 \pm 0.8 \mathrm{~cm}$; ages $1+$ and $2+$, respectively), and a minority is four years old or more (class IV, age 4+, with average length $8.5 \pm 0.8 \mathrm{~cm}$ ). Size overlaps between year classes and the attribution of the biggest crayfish to an age class by size is uncertain (as LAURENT, 1988). Mean growth rate is practically constant, at a mean value $2.2 \mathrm{~cm} /$ year, in our case (Figure 6). 

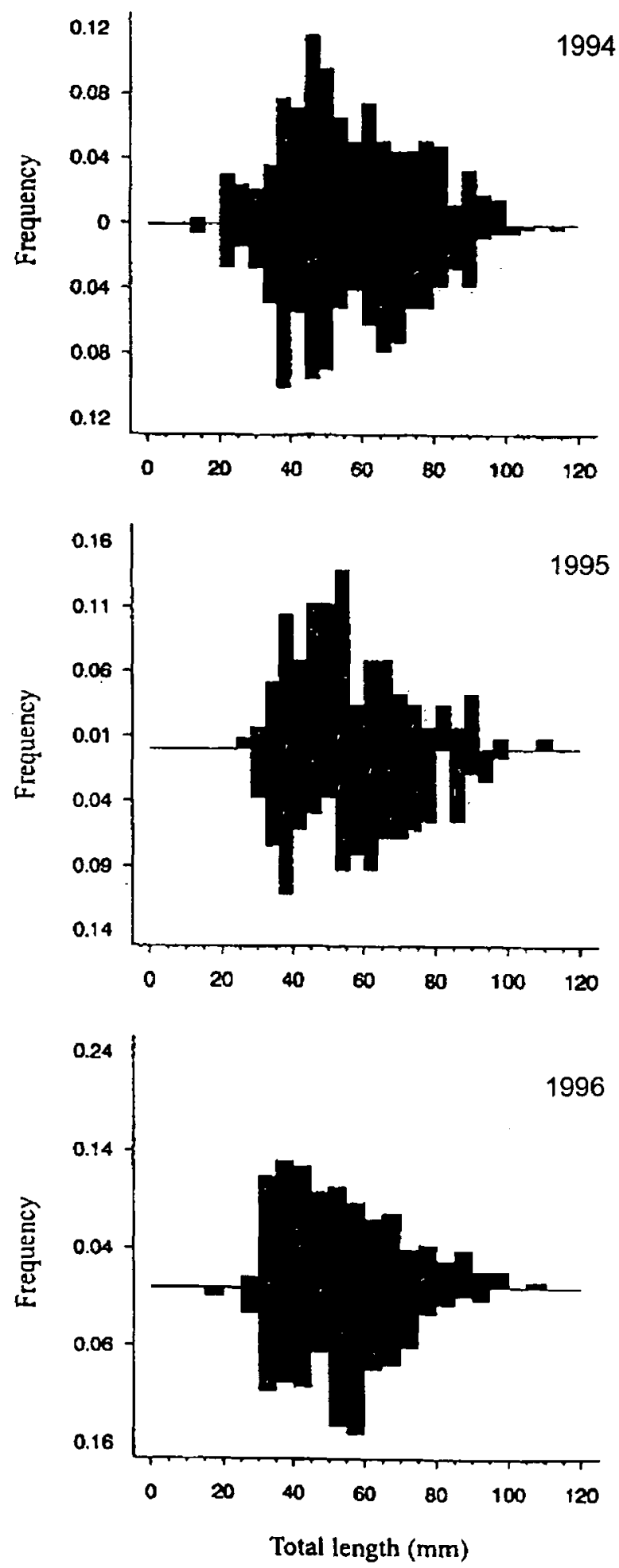

Figure 5

Frequency analysis of body lengths in three years. Above the axis : males; below : females.

Figure 5

Analyse de fréquence des tailles du corps sur trois ans. Au-dessus de l'axe : les mâles ; en-dessous, les femelles. 


\section{Table II}

Size groups determined by BATTACHARYA's method : average total-length, standard deviation, number and percentage of individuals belonging to each size group and separation index between groups (differences are significant when the index is greater than 2)

\section{Tableau II}

Groupes de taille déterminés par la méthode de BATTACHARYA : moyenne de la taille totale, écart standard, nombre et pourcentage d'individus appartenant à chaque groupe de taille et index de séparation entre les groupes (les différences sont significatives lorsque l'index est supérieur à 2)

\begin{tabular}{ccccc} 
& \multicolumn{4}{c}{1994} \\
\cline { 2 - 6 } size classes & $\mathrm{x} \pm \mathrm{ds}$ & $\mathrm{N}$ & $\%$ & $\mathrm{~S} . \mathrm{I}$ \\
I & $2 \pm 1.1$ & 66 & 9.5 & - \\
II & $4.6 \pm 0.8$ & 341 & 49.1 & 2.72 \\
III & $7.4 \pm 0.8$ & 236 & 34.0 & 3.65 \\
IV & $8.8 \pm 0.7$ & 51 & 7.4 & 2.06 \\
& \multicolumn{5}{c}{1995} \\
size classes & $\mathrm{x} \pm \mathrm{ds}$ & $\mathrm{N}$ & $\%$ & $\mathrm{~S} . \mathrm{I}$ \\
II & $3.8 \pm 0.5$ & 88 & 32.1 & - \\
III & $5.9 \pm 1.0$ & 142 & 51.8 & 2.72 \\
IV & $8.3 \pm 0.8$ & 44 & 16.1 & 2.64 \\
& & \multicolumn{4}{c}{1996} & \\
\cline { 2 - 6 } size classes & $\mathrm{x} \pm \mathrm{ds}$ & $\mathrm{N}$ & $\%$ & $\mathrm{~S} .1$. \\
II & $3.8 \pm 0.5$ & 164 & 40.6 & - \\
III & $5.6 \pm 0.6$ & 160 & 39.3 & 3.17 \\
IV & $8.5 \pm 0.8$ & 83 & 20.4 & 3.94
\end{tabular}

The shape of specimens has been studied by establishing morphometric relationships of the measures $T L$, cephalotorax length $(C L)$ and weight. The relationship between total length (TL) and cephalotorax length $(C L)$ is adjusted to the linear model $\mathrm{TL}=2.86+2.03 \times \mathrm{CL}\left(\mathrm{r}^{2}=98.97\right.$; number of cases $=1381 ;$ at $\left.95 \%\right)$. Testing TL by covariance analysis in order to extract the $\mathrm{CL}$ influence, significant differences in TL according to year and sex are detected (Figure 7). The following regression equations valid for cephalotorax lengths between 8 and $55 \mathrm{~mm}$ were thus obtained :

Year

Males

$r^{2} \quad$ N. cases

1994

1995

1996

Males
$\mathrm{TL}=3.63+1.98 \times \mathrm{CL}$
$\mathrm{TL}=3.27+1.99 \times \mathrm{CL}$
$\mathrm{TL}=4.33+1.92 \times \mathrm{CL}$

99.1

98.7

329

184
Females

$\mathrm{TL}=1.84+2.12 \times \mathrm{CL}$
$\mathrm{TL}=1.08+2.14 \times \mathrm{CL}$
$\mathrm{TL}=2.71+2.02 \times \mathrm{CL}$

$r^{2} \quad$ N. cases

$98.5 \quad 368$

$98.6 \quad 160$

$97.2 \quad 224$ 


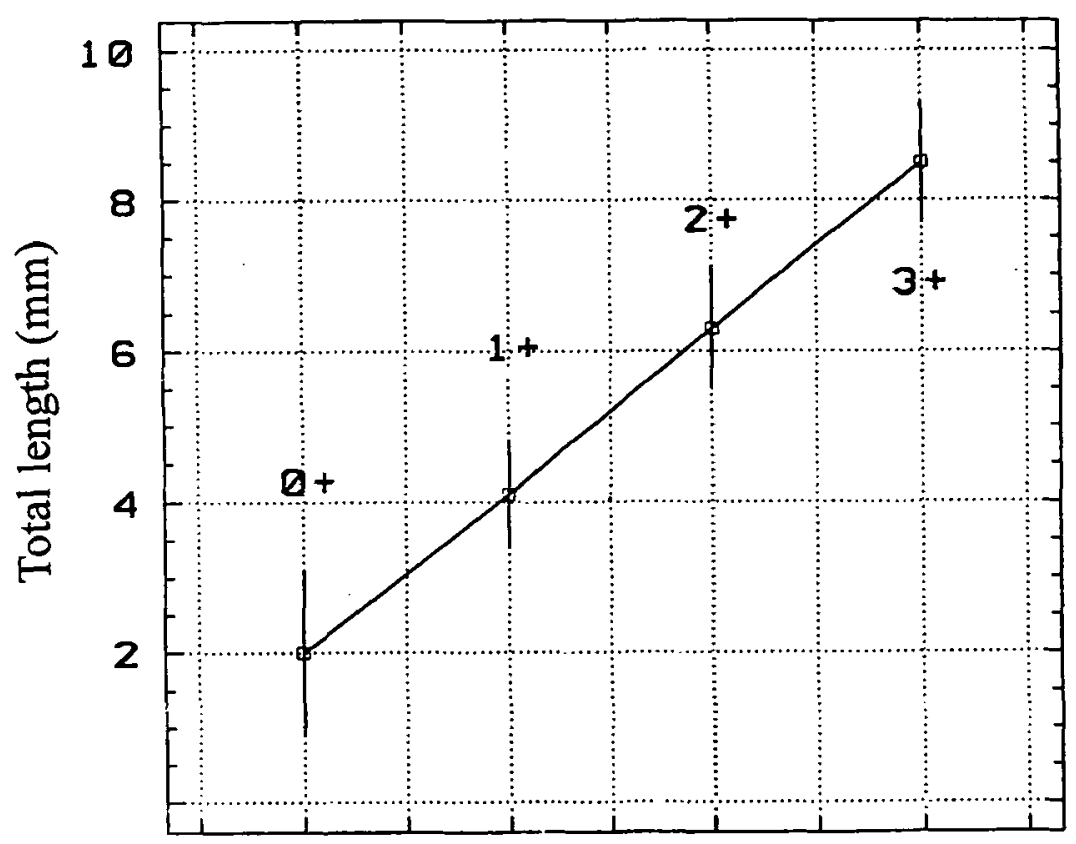

Age classes

Figure 6

Growth estimates : evolution of the average length of size classes.

Figure 6

Estimation de croissance : évolution de la longueur moyenne des classes de taille.

In general terms, total length is about double of cephalotorax length (less in males, $1.93 \pm 0.04 \mathrm{~mm}$; more in females, $2.09 \pm 0.06 \mathrm{~mm}$ ), plus a constant of $3.77 \pm 0.56$ in males and $1.86 \pm 0.84$ in females. These values differ significantly according to sexes (tested by Student's t-test at $95 \%$ ). As showed by comparison of slopes, females TL referred to CL is greater, so that they have relatively longer abdomens. From 1994 to 1996, a trend of diminishing TLTC might be detected for both sexes (Figure 7).

It is also interesting to examine the relationship between total length $(\mathrm{mm})$ and weight (g), and whether it varies according to sex and year or not. As generally is in the case of animals, the relationship is : $W=0.0002 \times \operatorname{TL}^{2.592}\left(r^{2}=91.47\right.$; number of cases $\left.=1,317\right)$. At a signification level of $95 \%$, weight differences not related with TL are detected between groups defined by sex, but not if classified by year (Figure 8) (ANCOVA analysis ; $n=1,317$ cases). So, two regression models are proposed:

\begin{tabular}{cccccc} 
Males & \multicolumn{3}{c}{ Females } \\
& $r^{2}$ & N. cases & & $r^{2}$ & N. cases \\
$W=0.0001 \times \mathrm{TL}^{2.761}$ & 92.7 & 604 & $\mathrm{~W}=0.0003 \times \mathrm{TL}^{2.450}$ & 91.0 & 713
\end{tabular}

The TL influence extracted as covariate, weight differences in averages are a little greater than those above calculated : males weight is $9.156 \pm 0.125 \mathrm{~g}$ and females $7.878 \pm 0.115 \mathrm{~g}$. That shows that, independently of size, males are heavier than females, surely because of carapace and chelipeds. The same is probed by the exponent being greater in males than in females. 


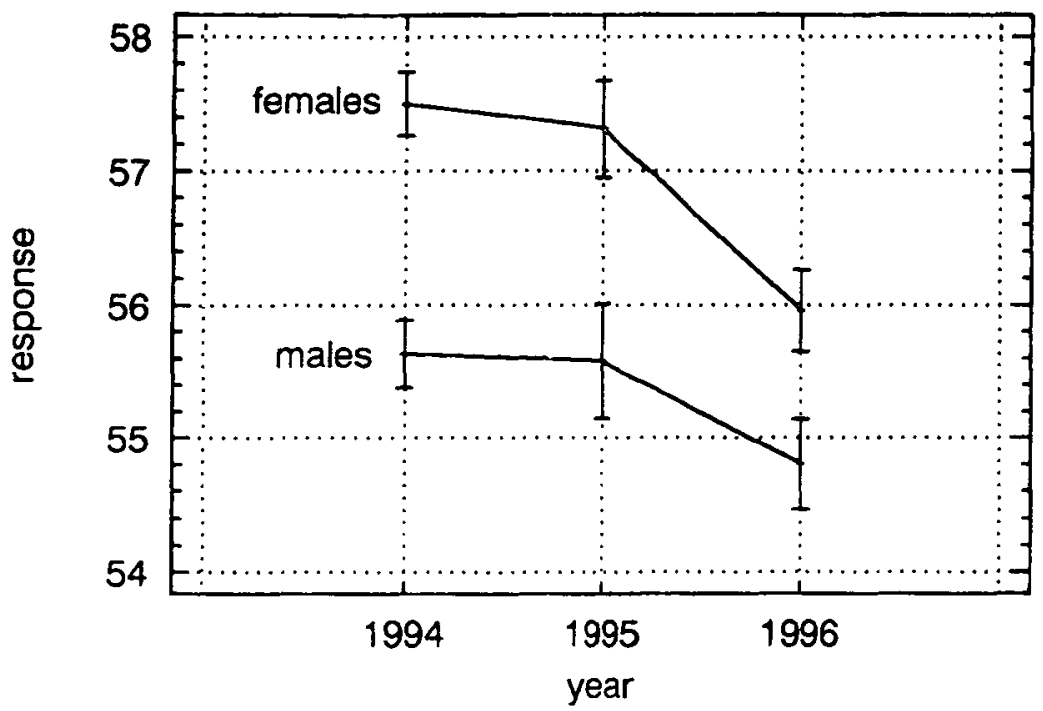

Figure 7

Differences in total length values in $\mathrm{mm}$ not explained by cephalotorax length variability (extracted by covariance analysis) according to sex and year.

\section{Figure 7}

Différences des valeurs de la longueur totale en $\mathrm{mm}$ qui ne sont pas exprimées par la variabilité de la longueur du céphalothorax (obtenues sur l'analyse de la covariance) selon le sexe et l'année.

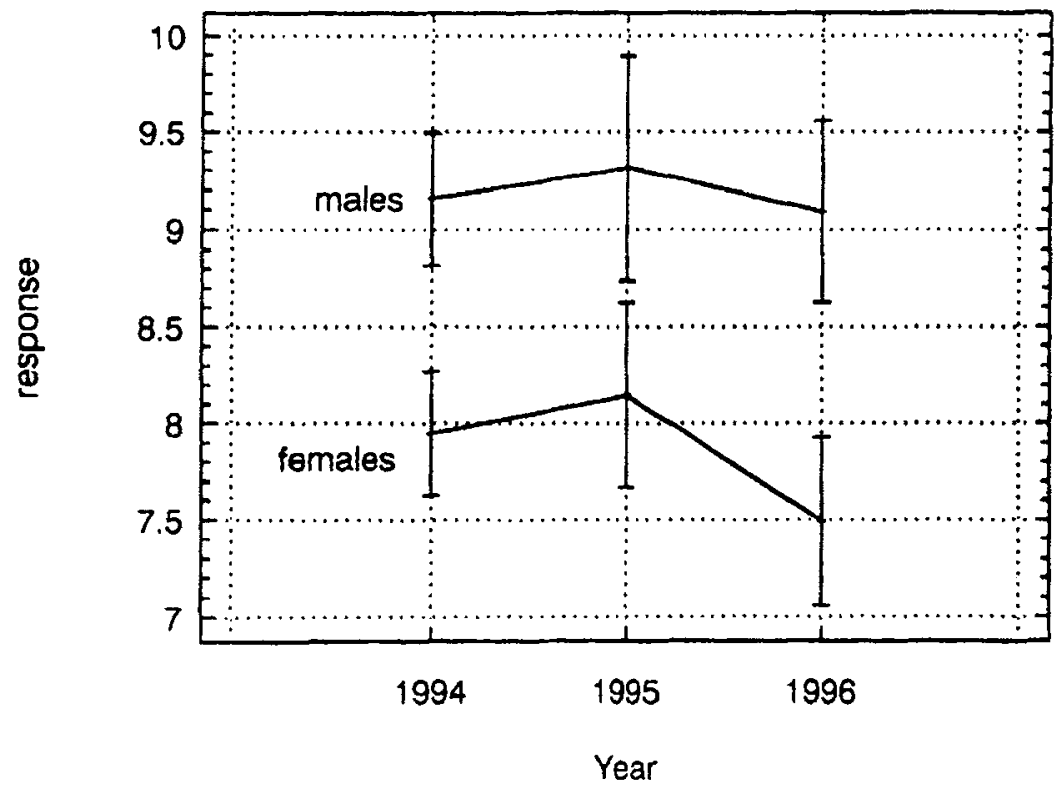

Figure 8

Differences in weight values in g not explained by total length variability (extracted by covariance analysis) according to sex and year.

Figure 8

Différences des valeurs du poids en g qui ne sont pas exprimées par la variabilité de la longueur totale (obtenues sur l'analyse de la covariance) selon le sexe et l'année. 


\section{Global conclusions and recommendations}

In short, the data and commentaries above are a first description of the situation of most cases of the populations of native craytish in Bizkaia's rivers. It may be accepted that they are residual populations, with a highly fluctuating demography, reduced to a few of specific sites with a highly fragmented distribution, and that they are in danger of extinction. Their habitat is characterized by a certain degree of conductivity and nutrients concentration.

Management measures for native crayfish conservation must include the protection and improvement of their habitat, prevention of access to it and the beginning and carrying out a genetic study to palliate the possible phenomenon of endemism. It would also be highly recommendable to start with experimental restocking of riverbeds now without crayfish fauna and apparently with the optimum in conditions for the establishment of populations of autochthonous crayfish.

\section{ACKNOWLEDGEMENTS}

This study was supported by the Departamento de Agricultura (Sección Pesca), Exma. Diputación de Bizkaia. We are specially indebted to E. ALVAREZ, Head of this Section, and to the river guard (gamekeepers) of Bizkaia. We wish also to acknowledge the observations of the referees.

\section{REFERENCES}

ALBA-TERCEDOR J., SÁNCHEZ-ORTEGA A., 1988. Un método rápido y simple para evaluar la calidad biológica de las aguas corrientes basado en el de Hellawell (1978). Limnetica, 4, 51-56.

ALMAÇA C., 1987. On the Portuguese populations of Austropotamobius pallipes (Lereboullet, 1858). Inv. Pesq., 51 (supl.1), 403-411.

ALMAÇA C., 1989. On the biology of north-eastern Portuguese populations of Austropotamobius pallipes (Lereboullet, 1858). Arch. Museu Bocage, nov. ser., I, 29, 419-428.

ARRIGNON J.C.V., ROCHÉ B., 1983. Population of the crayfish Austropotamobius pallipes pallipes LEREB. in a brook of Corsica, France. Freshwater Crayfish V, 229-238.

ARRIGNON J., MAGNE P., ATTARD J., ROCHÉ B., NICOD C., 1988. Dynamics of crayfishes populations Austropotamobius pallipes pallipes Lereboullet. Verh. Internat. Verein. Limnol., 23, 2114-2117.

ARRIGNON J., LAMY G., ROCHE B., 1993. Situation d'une population corse d'Austropotamobius pallipes pallipes (écrevisse à pattes blanches). In La production et l'exploitation des écrevisses en France. Assoc. Developm. Aquacult., pub. no 35 : 89-98.

BERNARDO J.M., ILHEU M., COSTA A.M., 1997. Distribution, population structure and conservation of Austropotamobius pallipes in Portugal. Bull. Fr. Pêche Piscic., 347, 617-624.

BHATTACHARYA G.C., 1967. A simple method of resolution of a distribution into gaussian components. Biometrics, 23, 115-135.

LAURENT P.J., 1988. Austropotamobius pallipes and A. torrentium, with observations on their interaction with other species in Europe. In HOLDICH D.M. and LOWERY R.S. (eds), Freshwater crayfish. Biology, management and exploitation, 341-364, The University Press, Cambridge. 
LILLEY A.J., BROOKER M.P., EDWARDS R.W., 1979. The distribution of the crayfish Austropotamobius pallipes (Lereboullet) in the upper Wye catchment, Wales. Nature in Wales, 16, 195-200.

MOMOT W.T.,1995. Redefining the role of crayfish in aquatic ecosystems. Rev. Fish. Sci., 3(1), 33-63.

RICO E., RALLO A., SEVILLANO M., ARRETXE M.L., 1992. Comparison of several biological indices based on river macroinvertebrate benthic community for assessment of running water quality. Annls Limnol., 28 (2), 147-156.

ROHLF F.J., 1992. NTSYS-pc. Numerical Taxonomy and Multivariate Analysis System. Exeter Software, N.Y., $215 \mathrm{p}$.

SMITH G.R.T., LEARNER M.A., SLATER F.M., FOSTER J., 1996. Habitat features important for the conservation of the native crayfish Austropotamobius pallipes in Britain. Biol. Conserv., 75, 239-246.

TROSCHEL H.J., 1997. Distribution and ecology of Austropotamobius pallipes in Germany. Bull. Fr. Pêche Piscic., 347, 639-647. 